dr hab. Piotr JEŻOWSKI, prof. SGH

Kolegium Ekonomiczno-Społeczne, Szkoła Główna Handlowa

e-mail: pjezow@sgh.waw.pl

DOI: $10.15290 /$ ose.2016.03.81.01

\title{
WKAAD EKONOMII HETERODOKSYJNEJ DO KONCEPCJI ROZWOJU ZRÓWNOWAŻONEGO
}

\begin{abstract}
Streszczenie
W opracowaniu wyjaśniono istotę trwałości jako podstawowego warunku zachowania kapitału naturalnego i jej znaczenie dla kategorii rozwoju zrównoważonego. W pracy opisano także, jak trwałość oraz rozwój zrównoważony są postrzegane i definiowane w ważniejszych dyscyplinach nauk ekonomicznych, a w szczególności w kierunkach heterodoksyjnych. W końcowej części podjęto problematykę związaną z promocją rozwoju zrównoważonego opartego na trwałości klimatycznej, ujętego w strategii „Europa 2020" i w pakiecie 2.0.
\end{abstract}

Słowa kluczowe: ekonomia heterodoksyjna, kapitał naturalny, trwałość, rozwój zrównoważony

\section{HETERODOX ECONOMICS CONTRIBUTION TO THE CONCEPT OF SUSTAINABLE DEVELOPMENT}

\begin{abstract}
Summary
The first at all, the paper explains the meaning of the term sustainability as a basic condition for keeping of natural capital assets for next generations and its impact on the sustainable development character. The second, it has been showed how sustainability and sustainable development are understood in the mainstream and heterodox economics. And, the third, the work shows the contemporary problems for implementation of sustainable development based on climate sustainability according to strategy Europe 2020 and the latest package 2.0.
\end{abstract}

Key words: heterodox economics, natural capital, sustainability, sustainable development

JEL: Q01, Q40, Q57, Q55

\section{Wstęp}

Celem opracowania jest wyjaśnienie istoty trwałości i jej podstawowego znaczenia dla kategorii rozwoju zrównoważonego oraz pokazanie, jak trwałość i rozwój zrównoważony są postrzegane i definiowane w ważniejszych dyscyplinach nauk ekonomicznych 
zarówno głównego nurtu, jak i heterodoksji. Dokonano równocześnie oceny wkładu ekonomii ekologicznej i innych dyscyplin ekonomii heterodoksyjnej w tworzenie koncepcji rozwoju zrównoważonego. Odniesiono się także do rozwoju zrównoważonego opartego na trwałości klimatycznej, który obecnie próbuje wdrażać Unia Europejska.

\section{Trwałość warunkiem zachowania kapitału naturalnego}

Rozwój zrównoważony (RZ) jest koncepcją stworzoną na potrzeby obejmujące wyzwania XXI wieku, opartą na myśleniu systemowym pozwalającym na zrozumienie związków między przyrodą a gospodarką i społeczeństwem w sytuacji: globalnego kryzysu ekologicznego, pułapki energetycznej oraz dramatycznych kwestii społecznych. Za podążaniem ku RZ przemawia świadomość przyszłych problemów związanych z przyrodą i jej ograniczonymi zasobami, gospodarką oraz społeczeństwem w warunkach globalizacji. Wynika ona z tego, że powielanie obecnych trendów rozwoju nie będzie miało racji bytu w nieodległej perspektywie. Rozwój zrównoważony stanowi dziś nieodłączny element nie tylko polityki ekologicznej, lecz także polityki społeczno-ekonomicznej i różnych strategii rozwoju na szczeblu: globalnym, państwowym, regionalnym i lokalnym. Koncepcja rozwoju zrównoważonego jawi się jako teoretyczna i praktycznie użyteczna podstawa zielonego kapitalizmu, który miałby wychodzić poza egoistyczne interesy i utarte miary wzrostu gospodarczego, również na rzecz wartości społecznych i ekologicznych.

Rozwój zrównoważony (sustainable development) jest przedmiotem szczególnego zainteresowania ekonomii ekologicznej. Specyficzne podejście prezentuje neoklasyczna ekonomia środowiska. Jednocześnie rozwój zrównoważony jest obecny w analizach wielu kierunków ekonomii heterodoksyjnej (np.: ekonomii neoinstytucjonalnej, ekonomii postkeynsowskiej, ekonomii behawioralnej) czy też kierunków zbliżonych do ekonomii głównego nurtu (np.: nowej ekonomii instytucjonalnej, nowej ekonomii keynesowskiej). Powstają nowe dyscypliny, które od początku biorą RZ za przedmiot zainteresowania i analizy. Istotny wkład wnoszą równocześnie nauki o zarządzaniu. Heterodoksja i nauki o zarządzaniu wskazują nie tylko na czynniki ekonomiczne, ale zarazem na rolę: instytucji, partycypacji społecznej, czynników sytuacyjnych, etyki i społecznej odpowiedzialności.

Zasadnicze znaczenie dla RZ ma podstawowy jego filar, na którym się opiera, tj. trwałość (sustainability), czyli etyczne i fizyczne warunki zachowania kapitału naturalnego. Etyczne ograniczenia korzystania z kapitału naturalnego obejmuja sprawiedliwość międzypokoleniową i wewnątrzpokoleniową oraz sprawiedliwość wobec bytów nieosobowych. Natomiast fizyczne ograniczenia to stosunek do substytucyjności kapitału naturalnego z pozostałymi formami kapitału i stosunek do nieodwracalności procesów.

Trwałość jest kategorią subiektywną, ponieważ są możliwe różne stopnie trwałości. Na subiektywizm, obok etycznych przesłanek zachowania kapitału naturalnego, może wpływać także niestabilność wartości społecznych oraz to, że przyjmowane założenia trwałości i koncepcje strategii rozwoju zrównoważonego wyrażają zwykle preferencje tych, którzy pracują nad nimi [Lambrecht, Thierstein, 1998, s. 101-110]. Od stopnia 
trwałości zależy to, czy akcentowane są bardziej problemy przyrody, czy też gospodarki lub społeczeństwa. Trwałość w kierunkach heterodoksyjnych (odchylenie ekologiczne) jest uznawana za główne kryterium rozwoju, natomiast w ekonomii głównego nurtu (odchylenie ekonomiczne) jest traktowana tylko jako element rozwoju.

Troska o kapitał naturalny i opowiedzenie się za wysokim stopniem trwałości stanowi niezaprzeczalny wkład ekonomii ekologicznej w promocję RZ. Kategoria kapitału naturalnego obecnie została przejęta już przez ekonomię środowiska i inne nauki społeczno-ekonomiczne. Mimo ewolucji, utrzymują się jednak różnice w podejściu do kapitału naturalnego, ponieważ poszczególne dyscypliny przypisują mu odmienne właściwości i funkcje. Ekonomia ekologiczna i zbliżone do niej dyscypliny wyránie rozgraniczają kapitał naturalny od kapitału wytworzonego przez człowieka i kapitału ludzkiego. Natomiast ekonomia środowiska i kierunki nurtu głównego nie podkreślaja tych różnic. Tu występuje konwencjonalne pojmowanie kapitału łącznego. Obejmuje on trzy typy kapitału, a mianowicie: wytworzony przez człowieka, ludzki oraz naturalny. Przez kapitał naturalny rozumie się tutaj jeden z wielu zamiennych zasobów, który może być odnawiany w podobny sposób, jak kapitał fizyczny i praca. W ekonomii ekologicznej hierarchia typów kapitału jest odwrócona z następującą sekwencją: kapitał naturalny, kapitał ludzki i kapitał wytworzony przez człowieka [Hediger, 1999, s. 7-9; Costanza, 2001, s. 459-468; Pearce, Atkinson, 1998, s. 251-269]. Najważniejszy jest kapitał naturalny, lecz w ekonomii ekologicznej wyjątkową wagę przypisuje się tym jego elementom, które tworzą ekosystemy. Ranga ekosystemów wynika z ich funkcji. Ekosystemy świadczą bowiem usługi ekologiczne niezbędne do utrzymania życia na Ziemi i usługi potrzebne do produkcji i konsumpcji. W szczególności są to według ważności:

- $\quad$ usługi ekologiczne podtrzymujace życie (life supporting environmental services), tj. usługi nieodzowne do podtrzymania wszelkiego życia i regeneracji ekosystemów;

- $\quad$ usługi umożliwiające samoregulację systemów, które utrzymująich zdolność wobec zewnętrznych szoków;

- $\quad$ inne usługi, które oddziałują na jakość życia, ale nie determinuja przetrwania albo reprodukcji ekosystemów (np.: rekreacyjne, estetyczne) [Collados, Duane, 1999, s. 441-460].

W rezultacie kapitał naturalny w ekonomii ekologicznej nie stanowi jednolitej kategorii. Elementy kapitału naturalnego są różnicowane na aktywa ważne i aktywa mniej ważne, jako kapitał krytyczny i pozostały (critical and non-critical natural capital), [Collados, Duane, 1999, s. 441-460].

Warunki zachowania całości lub części aktywów kapitału naturalnego określaja stopień trwałości. W ekonomii ekologicznej przyjmuje się co najwyżej ograniczona substytucję kapitału naturalnego z kapitałem fizycznym i ludzkim. Zasadniczo jest to warunek stałości sumy kapitału naturalnego ekosystemów, czyli stałość kapitału krytycznego. Odpowiada to trwałości mocnej (strong sustainability) ${ }^{1}$. Trwałość słaba (weak.

1 Założenie braku substytucyjności kapitału naturalnego z pozostałymi rodzajami (stałość całego kapitału naturalnego), przyjęte przez H. Daly'ego, odpowiada trwałości bardzo mocnej (very strong sustainability). 
sustainability) - charakterystyczna dla ekonomii środowiska - to stałość sumy kapitału: naturalnego, ludzkiego i wytworzonego przez człowieka [Żylicz, 2004, s. 197-198]. Trwałość w teorii neoklasycznej zakłada, że kapitał wytworzony i naturalny są substytutami, a utrata elementów kapitału naturalnego może być skompensowana korzyściami płynącymi z kapitału wytworzonego przez człowieka i kapitału ludzkiego [Rennings, Wiggering, 1997, s. 24-36].

\section{Postrzeganie rozwoju zrównoważonego w ekonomii}

Rozwój zrównoważony nie stanowi jednolitej i ściśle zdefiniowanej kategorii. Jest to koncepcja zmieniająca się w czasie i przestrzeni, płynna przedmiotowo i odzwierciedlająca różnice systemów wartości. Między rozwojem zrównoważonym opartym na trwałości słabej i mocnej istnieje szerokie spektrum jego różnych odmian i koncepcji.

Pierwotna definicja rozwoju zrównoważonego autorstwa G. Brundtlanda z 1987 roku jest ujęciem uogólnionym i oznacza: zaspokojenie potrzeb i aspiraciji dzisiejszego pokolenia w sposób, który nie ogranicza możliwości zaspokojenia potrzeb pryyszlym pokoleniom. W istocie jest to podejście normatywne, stanowiące próbę pogodzenia interesów obecnego pokolenia z interesami przyszłych pokoleń i mające na uwadze elementy rozwoju społecznego. Definicja ta jednak jest pozbawiona konkretności i wartości użytecznej wskazówki, jak należy kształtować cele polityki ekologicznej w nawiązaniu do celów polityki gospodarczej i polityki społecznej. W praktycznym wymiarze z potrzebami operacyjnymi związane jest konieczne większe sprecyzowanie: istoty, zakresu i zasad RZ.

W polskim prawie ochrony środowiska rozwój zrównoważony to: taki rožój spoteczno-gospodarczy, w którym nastepuje proces integrowania działan politycznych, gospodarcsych $i$ spotecznych ₹ zachowaniem równowagi prayrodniczej oraz trwatości podstawowych procesów prayrodnicsych, w celu zagwarantowania mo żliwości zaspokajania podstawouych potrzeb poszczególmych spotecżności lub obywateli, zarówno wspótczesnego pokolenia, jak i prayszłych pokoleń. Definicja ta ma cechy konkretności i dobrze oddaje istotę RZ.

Dotychczas nie udało się uzgodnić jednolitej definicji RZ, ponieważ na świecie funkcjonuje wielka liczba różnych definicji i interpretacji RZ - od skoncentrowanych na rozwoju społeczno-ekonomicznym, a pomniejszających problemy ekologiczne, do definicji ogniskujących nacisk na problemach ekologicznych, a ignorujących aspekty rozwoju gospodarczego i społecznego. Stanowi to istotny problem nie tylko poznawczy, lecz także praktyczny, gdyż RZ może być rozumiany i interpretowany na wiele sposobów, a realizowane polityki i strategie rozwoju mogą zawierać różne treści i zmienny zakres przedmiotowy.

Ekonomia ekologiczna (EE), wybierając trwałość mocna, zdecydowanie kładzie nacisk na trwałość ekologiczną i wielopokoleniowy horyzont. Ekonomia ekologiczna reprezentuje odchylenie ekologiczne, oparte na zasadach przepływów fizycznych, odrzucające preferencje społeczne jako błędne z powodu prezentyzmu [Daly, 2002, s. 1]. Jest to spojrzenie na gospodarkę przez pryzmat tzw. ekologicznego odcisku stopy ludzkiej (ecological footprint) [Wackernagel, Rees, 1997, s. 3-24] i oznacza nieodzowność utrzymania działalności człowieka w granicach istniejących aktywów ekologicznych. 
W ekonomii środowiska (ERE) jest obecne podejście pragmatyczne i tym samym koncentracja na trwałości ekonomicznej i wzroście gospodarczym. Tutaj rozwój zrównoważony definiuje się w warunkach słabej trwałości zakładającej, że kapitał naturalny i kapitał fizyczny są substytutami. Jedynie trwałość słaba, w której kapitał naturalny może być zastępowany kapitałem wytworzonym, umożliwia wzrost gospodarczy i rozwój zrównoważony [Jeżowski, 2012, s. 19-20].

Maksymalizm ekonomii ekologicznej i minimalizm ekonomii środowiska stały się zarzewiem ewolucji tradycyjnych kierunków ekonomii heterodoksyjnej i czynnikiem tworzenia się nowych kierunków ekonomii ${ }^{2}$. W heterodoksji nacisk kładzie się na czynniki behawioralne i sytuacyjne, a nie tylko na czynniki ekonomiczne i technologiczne. W analizie heterodoksja preferuje podejście jakościowe i eklektyzm metodologiczny.

Z tradycyjnych kierunków należy wyróżnić przede wszystkim neoinstytucjonalizm (IE) i równoległe: ekonomię ewolucyjną, ekonomię behawioralną (BE) oraz postkeynsizm (PKE). Neoinstytucjonalizm nie odżegnuje się od badania czynników: ekonomicznych, technologicznych, społecznych, kulturowych i instytucjonalnych, uznając wzajemne ich współzależności. W neoinstytucjonalizmie przyjmuje się, że w systemie ekonomicznym dużą rolę odgrywają instytucje. Reguły funkcjonowania biznesu i gospodarstw domowych, kreatywność, edukacja i uczenie się oraz doświadczenie wpływają na zmiany technologiczne, a w rezultacie pośrednio na wzorce produkcji i konsumpcji [Marechal, 2009, s. 74-83]. Tradycyjna heterodoksja odchodzi od modelu racjonalnego wyboru na rzecz ograniczonej racjonalności. Duże nadzieje wiąże się z postępami ekonomii behawioralnej, która bada procesy podejmowania decyzji, zachowań konsumentów i wartościowania dóbr, wyjaśniając prawdziwe przyczyny dokonywanych wyborów, odchylenia od logiki ekonomii i zachowania altruistyczne. Ekonomia behawioralna uwzględnia w analizie: czynniki psychologiczne, heurystykę dostępności, zakotwiczenie i inne anomalie, co powoduje, że wnioski z badań behawioralnych są przydatne w zarządzaniu środowiskiem i polityce ekologicznej.

Do nowego kierunku ekologicznej ekonomii politycznej zalicza się: teorię władzy, problemy pracy i rolę instytucji politycznych, zwłaszcza lokalnych. Zaleca się odejście od obiektywnego paradygmatu ERE i odrzucenie neoklasycznego rachunku ekonomicznego oraz uwzględnienie przestrzeni samorządu i państwa. Dlatego też istotne znaczenie mają reformy instytucji oraz rozwój społeczno-gospodarczy. Dyscyplina zakłada holistyczne widzenie kapitału: naturalnego, społecznego i fizycznego. Z kolei, ekonomia socjoekologiczna odwołuje się do wartości etycznych jednostek oraz kultury organizacyjnej, zwłaszcza organizacji rządowych i samorządowych, a także procesów uczenia się

\footnotetext{
2 Neoklasyczna ekonomia środowiska pod wpływem krytyki również zmienia podejście do kapitału naturalnego. Znamionami ewolucji ERE jest uwzględnienie m.in.: nieodwracalności, długiego okresu oraz zwrócenie większej uwagi na komplementarność aktywów naturalnych i fizycznych. Na dowód zmian podejścia można przytoczyć sugestie R. Ayresa, który sformułował racjonalne zalecenia długookresowej trwałości. Wymaga ona oparcia wzrostu gospodarczego bardziej na usługach i mniejszego uzależnienia od produktów materialnych i zasobów naturalnych w porównaniu z przeszłością, co, według niego, przyczyni się do tego, że przyszły wzrost będzie bardziej zależny od kapitału i pracy, które są w nadmiarze, a nie od zasobów naturalnych, których będzie coraz bardziej brakować [Ayres, 1998, s. 189-209].
} 
indywidualnego i grupowego. Przykłada się tu wielką wagę do wiedzy społecznej, kształtowanej przez: partycypację i praktyczne działanie w zespołach, edukację ekologiczna, szkolenia i otwarte dyskusje. Wiedza społeczna bowiem stwarza warunki do poprawnego wartościowania dóbr ekologicznych [Farber, Costanza, Wilson, 2002, s. 375-392]. Wiedza i partycypacja mogą także efektywnie przysłużyć się wypracowaniu, akceptacji i realizacji różnych strategii RZ. Najnowszą dyscypliną heterodoksji jest ekonomia rozwoju zrównoważonego. W zamiarze ma być to jednocześnie podejście holistyczne, wykorzystujące dotychczasowy dorobek nauk ekonomicznych i ściśle ukierunkowane na analizę RZ [Rogall, 2010, s. 26-27]. Wydaje się jednak, że jest ona przedwczesnym pomysłem wynikającym z mody na innowacje, również terminologiczne [Górka, 2010, s. 19].

Dyscypliny heterodoksyjne próbują zracjonalizować dorobek EE i ERE przez redefinicję relacji kapitału naturalnego z kapitałem ludzkim i fizycznym. Ich zainteresowania obejmuja równocześnie: politykę, instytucje publiczne, organizacje i kulturę organizacyjną oraz grupy społeczne. Tu, obok trwałości ekologicznej i ekonomicznej, w większej mierze uwzględniają trwałość: społeczna, polityczną i kulturowa. Ewolucja ekonomii pokazuje, że w erze rozwoju zrównoważonego nie ma miejsca na powrót do ekonomii głównego nurtu w jej czystej postaci. Tym samym rozwój RZ nie zostawia wiele miejsca na ekonomię opartą na uproszczonych założeniach.

Możliwość wyboru różnego stopnia trwałości prowadzi do licznych odmian RZ. Konkretne rozwiązania zależą bowiem od: czasu, miejsca, wyznawanych wartości i dysponowanych zasobów naturalnych, ekonomicznych i ludzkich, jak i od tego, kto jest ich autorem. W konsekwencji RZ jest kategoria: płynna, niejednoznaczną i obarczona subiektywizmem. Dodatkowy zamęt powoduje wielka popularność tego terminu. Dlatego niekiedy trudno ocenić, czy mamy do czynienia z realną kategorią ekonomicznoekologiczna, czy też tylko ze słowem-wytrychem lub chwytem marketingowym, który ma na celu poprawę wizerunku: administracji, instytucji sektora publicznego oraz firm, szczególnie wielkich koncernów transnarodowych.

O ile nierozstrzygnięty spór dotyczy wyboru stopnia trwałości, o tyle panuje zgoda w tym, że łącznie należy brać pod uwagę i analizować trzy typy kapitału (tj.: naturalny, ludzki i fizyczny). Mimo swej wieloznaczności, RZ ma lub powinien mieć elementy wspólne. Powinien być zachowany długoterminowy punkt widzenia w stosowaniu zasad ochrony środowiska i oszczędnego gospodarowania zasobami naturalnymi oraz musi być uwzględniona zasada przezorności wobec kapitału naturalnego i zasady sprawiedliwości [Mulder, van der Bergh, 2001, s. 110-134].

Warto zauważyć, że rozwój zrównoważony nie jest rozwojem społecznym, skoncentrowanym na człowieku i ujmującym problemy: zdrowia, edukacji i zatrudnienia ${ }^{3}$. Nie jest zarazem rozwojem gospodarczym, który z natury skupia się na: produkcji, dochodach i konsumpcji. Rozwój zrównoważony nie jest także rozwojem przestrzennym, skoncentrowanym na optymalnym zagospodarowaniu przestrzeni. Jednocześnie rozwój zrównoważony nie może oznaczać wyłącznie rozwoju ekologicznego. Wybór jednej z tych opcji musiałby wiązá́ się z naruszeniem sprawiedliwości: ekologicznej,

${ }^{3} \mathrm{Na}$ przykład raport „Polska 2030. Wyzwania rozwojowe” nie jest zarysem prawdziwej strategii RZ, ponieważ uwzględnia tylko kapitał społeczny i gospodarczy, natomiast pomija kapitał naturalny. 
społecznej, przestrzennej lub ekonomicznej. Konieczne jest podejście zintegrowane, uwzględniajace równocześnie te wartości, których rachunek ekonomiczny i metody szacowania nie obejmują wartości ekonomicznych ${ }^{4}$.

Rozwój zrównoważony oparty na trwałości mocnej jest podejściem bardzo ambitnym, ponieważ wymaga realnych poświęceń obecnego pokolenia, aby dla przyszłych pokoleń zachować kapitał naturalny, w tym jego krytyczny składnik. Łączy się to z kosztami, które należy ponieść dzisiaj, by uniknąć wysokich kosztów w przyszłości. Ponadto, skala gospodarki powinna być dostosowana do rozmiarów zasobów naturalnych. Trwałość mocna pozostawia niewiele miejsca na rozwój społeczno-gospodarczy i zapewnienie dobrobytu obecnemu pokoleniu. Faktycznie jest to spektrum wyznaczonych możliwości asymilacyjnych środowiska i zasobów kapitału naturalnego. W konsekwencji ambicje ekonomii ekologicznej i strategie oparte na mocnych wariantach RZ są trudne do zaakceptowania przez obecne pokolenie. Trwałość mocna pomija krótkookresowe interesy gospodarki i społeczeństwa i może być przyjęta bardziej za niedościgły wzorzec niż realistyczny cel możliwy do osiagnięcia w dzisiejszych uwarunkowaniach społeczno-politycznych. W szczególności niełatwo sprostać tym wymaganiom na niższych szczeblach zarządzania, tj. w przedsiębiorstwach i gminach. Tu bowiem przyjęcie zasad RZ w mocnych wariantach napotyka znacznie więcej ograniczeń niż na poziomie makro. Na szczeblu lokalnym nieodzowne jest uwzględnienie nie tylko interesów środowiska, lecz również gospodarki i społeczeństwa (przedsiębiorczość, zatrudnienie, wyrównywanie szans, walka z ubóstwem, dostęp do usług zdrowotnych i edukacyjnych czy też partycypacja w istotnych decyzjach gospodarczych, społecznych i politycznych). Z kolei, rozwój zrównoważony oparty na trwałości słabej to podejście mało ambitne i niewystarczające, niemniej jednak bardziej realistyczne, łatwiejsze do wdrożenia oraz wykonalne ze względu na szerszą akceptację społeczną i polityczna.

W praktyce wybiera się pośrednie bądź racjonalne warianty trwałości, które są w miarę gospodarczo i społecznie akceptowalne, uwzględniające rozsądne zasady zachowania kapitału naturalnego, mimo że zawsze pojawia się pytanie, czy obecne społeczeństwa moga żyć na koszt przyszłych.

Zasługą ekonomii ekologicznej jest to, że wskazała na zróżnicowaną rolę elementów kapitału naturalnego, a w szczególności rolę krytycznego kapitału naturalnego, który warunkuje system podtrzymujący życie. Współczesne pokolenie nie jest jeszcze przygotowane do przyjęcia za cel trwałości mocnej. Racjonalny wybór trwałości leży w przestrzeni między ambitnym podejściem EE a niedostatecznym podejściem ERE. W strategiach RZ ważne jest spożytkowanie nie tylko sprawiedliwości wobec przyszłych generacji (trwałość ekologiczna), ale także postrzeganie interesu gospodarki i obecnego pokolenia (trwałość ekonomiczna i społeczna). Bez tego strategie te są niewykonalne,

${ }^{4}$ Należy podkreślić, że istota RZ nie tkwi w równoważeniu relacji między takimi ładami, jak: gospodarka, społeczeństwo, przestrzeń czy przyroda, ale w wyborze stopnia trwałości i racjonalnej integracji różnych jego aspektów. Stopień trwałości zawsze bowiem określa nacisk na ochronę środowiska oraz dbałość i siłę dążenia do zachowania kapitału naturalnego względem potrzeb gospodarki i potrzeb społeczeństwa w obecnym pokoleniu [Jeżowski, 2007, s. 16]. 
ponieważ brak im akceptacji społeczno-politycznej. Podejścia: neoinstytucjonalizmu, ekonomii ewolucyjnej, ekonomii behawioralnej i ekonomii socjoekologicznej oraz pozostałej heterodoksji starają się mieć na uwadze uwarunkowania społeczne i polityczne przez próby integracji elementów: ekonomii, ekologii, socjologii i politologii z uwzględnieniem dynamiki różnych struktur organizacyjnych i ich kultur. W szczególności zapewnienie i zachęta do partycypacyjnego i świadomego charakteru tworzenia strategii RZ pozwala na uniknięcie wielu konfliktów i sprzeczności interesów. Złagodzone podejście jest bliższe realiom społeczno-ekonomicznym i stwarza lepsze perspektywy na większą akceptację społeczna polityki ekologicznej i strategii rozwoju zrównoważonego. Mniej dogmatyczny RZ, uwzględniający również rozwój społeczno-ekonomiczny, jest szansa nie tylko ograniczania degradacji środowiska, lecz jednocześnie sprzyja dobrobytowi społecznemu.

\section{Rozwój zrównoważony w warunkach trwałości klimatycznej}

Jako sprawę zasadniczą dla współczesnego definiowania i rozumienia kategorii rozwoju zrównoważonego należy podkreślić, że w ostatnich dwu dekadach nastapiła wyraźna zmiana wynikająca z uznania katastroficznych opinii pewnej części klimatologów. Heterodoksja dała się wyprzedzić w precyzowaniu trwałości ekonomii globalnego ocieplenia czy tzw. the new climate economy. Odchylenie klimatyczne lub przewrót klimatyczny sprokurowane przez nie-ekonomistów i klimatologów stanowią sui generis schizmę względem teoretycznych ustaleń koncepcji rozwoju zrównoważonego. W koncepcji trwałości klimatycznej przed tradycyjne obszary problemowe RZ, takie jak: zanieczyszczenie powietrza trującymi substancjami, odpady, transport, gospodarka materiałowa, energia, woda i ścieki, żywność, gospodarka przestrzenna i bioróżnorodność, kultura i dziedzictwo kulturowe, sprawiedliwość, gospodarka oraz zdrowie, na pierwsze miejsce wysunęła się ochrona klimatu i gospodarka niskowęglowa.

Nowa hierarchia problemów ma obecnie zasadniczy wpływ na kształtowanie priorytetów ekologicznych, społecznych i ekonomicznych na poziomie: globalnym, państwowym, regionalnym i lokalnym. Przesunięcie akcentów przyczynia się do tego, że niektórzy błędnie wręcz utożsamiają ochronę klimatu i gospodarkę niskowęglową z rozwojem zrównoważonym. Takie jednostronne uproszczenie i sprowadzanie wszystkiego do ochrony klimatu i dekarbonizacji jest niebywałym nadużyciem merytorycznym $\mathrm{i}$ intelektualnym, wiodącym niekiedy do naciagania argumentów i zwykłego oszustwa. Śmieszyć musza próby, czasem cyniczne, wiązania praktycznie wszystkich dziedzin działalności człowieka z wpływem na klimat czy też poszukiwania wątpliwych związków między temperaturą a zjawiskami meteo na podstawie heurystyki dostępności. Jest to skutek proliferacji na niespotykaną skalę myślenia grupowego i zatracenia krytycyzmu w osądach, a przede wszystkim pomijania istotności parametrów ekonomicznych i społecznych. Intensywność propagandy klimatycznej, katastrofizm, religijne podejście i rosnące zaangażowanie każą przypuszczać, że w całej sprawie nie do końca chodzi o ochronę klimatu, gdyż tak naprawdę człowiek nic nie ma do klimatu i nie może sobie przypisywać boskich przymiotów, a o interesy ekonomiczne. 
Oparcie rozwoju zrównoważonego na trwałości klimatycznej rodzi wiele istotnych pytań, zwłaszcza gdy globalizacja coraz wyraźniej ukazuje swoje nieludzkie oblicze, a mianowicie:

- $\quad$ czy ochrona klimatu jest najpilniejszym wyzwaniem ludzkości, jeśli się rozważy zagrożenie: globalnym kryzysem finansowym $i$ gospodarczym, bankructwami państw, wojnami i falami uchodźców czy cyberprzestępczością?

- $\quad$ czy etyczna jest ochrona klimatu, kiedy na świecie szerzą się: ubóstwo skrajne, niedostępność podstawowych usług publicznych, epidemie i choroby cywilizacyjne?

- $\quad$ czy walka z ociepleniem klimatu ma ograniczać wysiłki w zakresie ochrony środowiska?

- $\quad$ czy model klimatyczny ma coś wspólnego z demokracją czy raczej rodzajem totalitaryzmu, zalążkiem niewidzialnego rządu światowego?

- $\quad$ czy rozwój prowadzący do nadmiernych wyrzeczeń i bólu ludzi jest godny miana rozwoju zrównoważonego?

Zmodyfikowane rozumienie RZ występuje w podstawowych dokumentach Unii Europejskiej odnoszących się do polityki klimatyczno-energetycznej, takich jak pakiet $3 \times 20$, obecnie obowiazzująca strategia „Europa 2020”, zarys strategii klimatyczno-energetycznej 2030 oraz dalsze plany na perspektywę 2050. Strategia „Europa 2020” obejmuje trzy wzajemnie ze soba powiazane priorytety:

- rozwój inteligentny: rozwój gospodarki opartej na wiedzy i innowacji;

- $\quad$ rozwój zrównoważony: wspieranie gospodarki efektywniej korzystającej z zasobów, bardziej przyjaznej środowisku i bardziej konkurencyjnej;

- $\quad$ rozwój sprzyjający włączeniu społecznemu: wspieranie gospodarki o wysokim poziomie zatrudnienia, zapewniającej spójność społeczną i terytorialna.

W tej strategii rozwój zrównoważony - na pierwszy rzut oka - może być rozumiany szeroko jako holistyczne postrzeganie ładu gospodarczego, ładu ekologicznego i ładu społecznego. Natomiast priorytet drugi ogranicza rozumienie rozwoju zrównoważonego do wspierania gospodarki w efektywnym wykorzystaniu zasobów naturalnych i ochrony środowiska oraz niedookreślonej czasowo gospodarki bardziej konkurencyjnej. Jednak pod hasłem ochrony środowiska de facto kryją się przede wszystkim cele klimatyczne i walka z paliwami kopalnymi, głównie z węglem. Trudno także założyć, że restrykcyjna polityka klimatyczna idzie w parze z podniesieniem konkurencyjności wszystkich gospodarek państw członków Unii Europejskiej czy też z osiagnięciem dostępnych cen energii ${ }^{5}$. Wręcz przeciwnie, jest to istotny czynnik wzrostu cen energii w Europie, jeszcze bardziej pogłębiający rozziew ich poziomu w porównaniu z USA. W rezultacie w Unii Europejskiej rzecz toczy się o zupełnie inny rozwój zrównoważony - rozwój klimatyczny.

O ile włączenie kwestii społecznych do strategii Unii Europejskiej jest zgodne z sugestiami agend ONZ i międzynarodowych gremiów naukowych, to zakwestionowanie trwałości paliw kopalnych jest podejściem nierealistycznym i wyprzedzającym globalne

\footnotetext{
${ }^{5}$ Hasła ochrony nieodnawialnych zasobów energetycznych przez wykluczenie węgla, głoszone przez wielu ekologów w Unii Europejskiej, trącą cynizmem.
} 
porozumienie klimatyczne o istotnym, a nie powierzchownym znaczeniu ${ }^{6}$. Bez USA i Chin nie można wiele osiagnąć w redukcji światowej emisji $\mathrm{CO}_{2}$. Nota bene samotna walka Unii Europejskiej z $\mathrm{CO}_{2}$ jest szkodliwa dla klimatu ze względu na migrację przemysłu energochłonnego do gospodarek wschodzących. W układzie globalnym pożegnanie z paliwami kopalnymi to przedwczesne hasło. Po pierwsze, dla gospodarki światowej sprawa zasadnicza jest długofalowe zapewnienie energii oraz ochrona zasobów i środowiska, a nie walka z $\mathrm{CO}_{2}$. Po drugie, procesy restrukturyzacji energetyki wymagaja długiego okresu.

Unia Europejska nie ma jasnej polityki gospodarczej ani polityki przemysłowej, ale włada polityką klimatyczną, która służy zawoalowaniu wszystkich problemów gospodarczych. Nie jest możliwe, aby polityka klimatyczna zastapiła politykę energetyczna i przemysłowa. Przemieszanie priorytetów prowadzi do odrealnienia obrazu świata w oczach biurokracji brukselskiej. Na arenie międzynarodowej Unia Europejska staje się coraz mniej wiarygodna, pomimo zapewnien, że jest odwrotnie. Unia Europejska przegrywa na polu politycznym, militarnym i gospodarczym. Wiedzie to do systematycznej marginalizacji wspólnoty europejskiej względem USA i gospodarek wschodzących $^{7}$.

W strategii „Europa 2020” wykorzystanie zasobów i ochrona klimatu są ujęte w konkretne, ilościowe wskaźniki, natomiast konkurencyjność już nie. Jej słabą strona jest także brak odniesienia do kosztów, co potwierdza, że polityka klimatyczna ma pierwszeństwo przed polityką przemysłową

Jeszcze gorzej to wygląda w propozycjach na perspektywę 2030, a zwłaszcza w ostatecznych ustaleniach pakietu 2.0. Kluczowe elementy tej strategii, uwzględnionej w opracowaniu Komisji Europejskiej 2030 Climate and Energy Framework (CEF), przedstawiono następująco:

\footnotetext{
${ }^{6}$ Klęski kolejnych COP i szczytów Ziemi powinny dać do myślenia biurokracji brukselskiej, a przynoszą efekt przeciwny - rosnące zaangażowanie, co jest przejawem alienacji i życzeniowego myślenia oraz braku trzeźwego osądu, a także przejawem naiwności i utopijnego postrzegania świata. Ambitny przykład Unii Europejskiej nie robi wrażenia na: USA, Chinach czy Indiach. Na tym poziomie nie można nikogo zaskoczyć swoją przebiegłością, rzucając coraz to wyższe wskaźniki redukcji $\mathrm{CO}_{2}$. Gołym okiem widać, że Unia Europejska, windując wskaźniki redukcji $\mathrm{CO}_{2}$, chce w fałszywy sposób zadbać o własną konkurencyjność względem gospodarek zewnętrznych. Stąd nie należy oczekiwać, że następne spotkania międzynarodowe przyniosa zasadniczy zwrot w uzgodnieniach klimatycznych, zwłaszcza gdy Unia Europejska dalej będzie stawiać na wyśrubowane wskaźniki redukcji $\mathrm{CO}_{2}$.

${ }^{7}$ Wskaźnikiem słabnięcia gospodarczej pozycji Europy jest liczba miliarderów i jej przyrost. W tym zakresie Unię Europejską wyprzedziły nie tylko USA, lecz również Chiny i Indie.

8 Praktycznie na osiem celów ilościowych strategii „Europa 2020” aż trzy są związane z klimatem i energia。 co oznacza, że ich realizacja jest całkowicie sprzeczna z zapewnieniem wzrostu konkurencyjności Europy wobec USA i kluczowych gospodarek wschodzących. Nadrzędne w zamiarze i wymierne cele strategii „Europa 2020” to:

- $\quad$ wskaźnik zatrudnienia osób w wieku 20-64 lata powinien wynosić 75\%;

- $\quad$ na inwestycje w badania i rozwój należy przeznaczać 3\% PKB Unii;

- $\quad$ trzeba osiagnąć cele „20/20/20” w zakresie klimatu i energii (w tym ograniczenie emisji $\mathrm{CO}_{2}$ nawet o $30 \%$, jeśli pozwolą na to warunki);

- liczbę osób przedwcześnie kończących naukę szkolną należy ograniczyć do 10\%, a co najmniej $40 \%$ osób z młodego pokolenia powinno zdobywać wyższe wykształcenie;

- $\quad$ liczbę osób zagrożonych ubóstwem należy zmniejszyć o $20 \mathrm{mln}$.
} 
- obniżenie o 40\% emisji $\mathrm{CO}_{2}$ na poziomie całej Unii Europejskiej (ETS and non-ETS);

- $\quad$ uzyskanie co najmniej 27-procentowgo udziału OZE w bilansie energetycznym na poziomie całej Unii Europejskiej;

- uzyskano poprawy efektywności energetycznej;

- odniesienie do bezpieczeństwa dostaw energii i konkurencyjności;

- reforma Unii Europejskiej ETS;

- nowy system współrządzenia (governance).

Ostatecznie na szczycie Unii Europejskiej w październiku 2014 roku został przyjęty pakiet 2.0, w którym ustalono:

1. Wiążący cel klimatyczny (obniżenie emisji $\mathrm{CO}_{2}$ co najmniej o 40\% od $1990 \mathrm{roku}$ ):

- $\quad$ ETS - 43\% od 2005 roku;

- $\quad$ non-ETS - 30\% od 2005 roku (szczególnie uciążliwa nowość);

2. Niewiążące cele klimatyczne (OZE - 27\% i efektywność energetyczna - 27\%);

3. Darmowe uprawnienia emisyjne $\mathrm{CO}_{2}$ dla unijnych biedaków po 2020 roku bez rozstrzygnięcia, kto dokładnie i jak spełni warunki uzyskania uprawnień emisyjnych';

4. Mechanizm ręcznego sterownia EU E TS (backloading) ${ }^{10}$.

Na podstawie CEF i pakietu 2.0 można wyraźnie zauważyć, że obecnie Unii Europejskiej praktycznie chodzi tylko o redukcję $\mathrm{CO}_{2}$, gdyż nawet racjonalne cele OZE i efektywności energetycznej nie mają równorzędności, jak w pierwotnym pakiecie $3 \times 20$. Zawężające rozumienie rozwoju zrównoważonego i naiwne trzymanie się nierealistycznych celów klimatycznych w Unii Europejskiej kontrastuje z podejściem do rozwoju zrównoważonego przez agendy Organizacji Narodów Zjednoczonych. Instytucje ONZ jasno widzą problemy ubogich państw i nie próbują na siłę przestawić polityki energetycznej państw gospodarek wschodzacych. Ochrona klimatu nie zajmowała czołowej pozycji w dotychczasowych milenijnych celach rozwoju ani też nie będzie kluczowa w obecnie uzgadnianych celach Agendy Post 2015.

W strategii Unii Europejskiej mają pierwszeństwo kosztowne technologie wytwarzania energii z OZE z wieloma realnymi ułatwieniami dającymi OZE nadzwyczajna rentę konkurencyjności w stosunku do energetyki konwencjonalnej. Jest to ogromne wsparcie finansowe zarówno na etapie inwestycyjnym, jak i w trakcie bieżącego funkcjonowania, a także wymuszone pierwszeństwo w odbiorze tej energii o zdecydowanie niskiej jakości przez systemy dystrybucyjne. Energetyka konwencjonalna jeszcze musi zmagać się z dodatkowym utrudnieniem, a mianowicie, handlem $\mathrm{CO}_{2}$, który per saldo jest

\footnotetext{
${ }^{9}$ Dla Polski darmowe uprawnienia to tylko odsunięcie polskich problemów w czasie.

${ }^{10}$ Dotychczas system EU ETS systematycznie bankrutował, ponieważ nie można ad hoc racjonalnie zaplanować liczby darmowych uprawnień na podstawie historycznych danych, a zapotrzebowanie zależy od koniunktury gospodarczej. Kryzys gospodarczy uwalniał ogromną liczbę pozwoleń, dając z jednej strony niezasłużone zyski niektórym przedsiębiorstwom, a z drugiej prowadząc do niskich cen giełdowych uprawnień. Stąd w Unii Europejskiej zrodziła się pokusa ręcznego sterowania ich cenami, w istocie przekształcająca ten instrument ekonomiczny w instrument administracyjno-prawny.
} 
czynnikiem kosztotwórczym energii wytwarzanej w tradycyjnych technologiach węglowych ${ }^{11}$. Oba kierunki działania sztucznie zmieniają relacje ekonomiczne podsektorów energii i bez wątpienia jednocześnie zakłócają mechanizm rynkowy. W konsekwencji w Europie nie widać szans na obniżenie kosztów i cen energii, bowiem oba źródła pozyskania energii stają się bardzo drogie, w równej mierze te oparte na OZE, jak i te tradycyjne. To razem powoduje ucieczkę europejskiego przemysłu do USA i gospodarek wschodzących oraz obniżenia konkurencyjności gospodarek europejskich, co w istocie jest przeciwstawne celom, jakie przyświecaja strategii „Europa 2020” i zarysowi strategii „Europa 2030”.

W kontekście zmian polityki klimatyczno-energetycznej Unii Europejskiej nie ma żadnych nadziei na obniżenie cen energii. Przez nacisk na dekarbonizację będą rosnąć koszty energii elektrycznej i cieplnej ze źródeł tradycyjnych. Nie można także oczekiwać, że model niemieckiej Energiewende okaże się zawodny. Wręcz przeciwnie, model energetyki odnawialnej, zdecentralizowanej, regionalnej i lokalnej oraz prosumenckiej staje się wzorcem do naśladowania. Mimo to będą równocześnie rosły koszty energii ze źródeł odnawialnych, ponieważ zakres pomocy publicznej będzie systematycznie kurczył się. Unia już wie, że nie jest w stanie sfinansować swoich nadmiernych ambicji w zakresie promocji OZE. Stąd mają miejsce ograniczenia, instrumenty zwrotne i PPP czy też przenoszenie ciężaru finansowego na wszystkich członków wspólnoty. Jednakże wpływ wzrostu kosztów energii na gospodarkę i społeczeństwo ma inny wydźwięk w państwach przewodzących Unii Europejskiej, a inny w państwach na niższym stopniu rozwoju (osiagnięcie celów polityki klimatycznej różnie się przekłada na państwa członkowskie, ponieważ koszty niejednakowo obciążaja PKB per capita).

Poza tym, mało kto w Europie zastanawia się nad bezpieczeństwem energetycznym, co jest bezsprzecznie miernikiem stopnia alienacji biurokracji unijnej. Polityka energetyczna związana w uścisku z polityką klimatyczna powinna uwzględniać potrzeby nie tylko najbogatszych państw członkowskich Unii Europejskiej, lecz także pozostałych interesariuszy. Jeśli ma ona równolegle prowadzić wobec niektórych do nadmiernego wysiłku, biedy i realnego wykluczenia społecznego - zjawisk watpliwych z punktu widzenia społecznego - to trudno ją uznać za zgodną z rozwojem zrównoważonym.

\section{Konsekwencje dla Polski}

Marcowy szczyt Rady Europejskiej nie daje złudzeń dotyczących dalszego kierunku polityki Unii Europejskiej. Ramowa struktura unii energetycznej ma opierać się na pięciu filarach, tj.: solidarności i zaufaniu, zintegrowanym europejskim rynku energii, efektywności energetycznej, bezpieczeństwie energetycznym, dekarbonizacji gospodarki,

11 Nota bene system EU ETS jest instrumentem niezmiernie drogim nie tylko przez wplyw na hamowanie przedsiębiorczości oraz obciążenie gospodarki i społeczeństwa, lecz również ze względu na koszty administracji systemu oraz narażenie na oszustwa i kradzież. Prowadzenie systemu to nie „darmowy obiad", gdyż implikuje funkcjonowanie ogromnej biurokracji na poziomie państwowym i unijnym. Te same cele klimatyczne Unia Europejska i świat osiagnęłyby po znacznie niższych kosztach i sprawiedliwiej za pomocą taniego podatku ekologicznego (węglowego). 
badaniach naukowych oraz innowacyjności i konkurencyjności. O ile kwestia europejskiego zintegrowanego rynku energii jest na razie fikcyjna koncepcja, to dekarbonizacja jest dla Polski groźnym wyzwaniem. Jak zaznaczył K. Szymański, unia energetyczna niewiele wnosi do bezpieczeństwa energetycznego i cen energii, natomiast będzie wehikutem dla zaostrzonej polityki klimatycznej UE [Zob. Unia Energetyczna..., 2015]. Funkcjonariusze Unii Europesjkiej nie ukrywają także tego, że unia energetyczna ma pozwolić Polsce wywiązać się z wysokich wymogów narzucanych w strategiach unijnych ${ }^{12}$.

Pakiet $2.0 \mathrm{w}$ ogólnym zarysie jest szkodliwy dla polskiej gospodarki ze względu na:

- wzrost kosztów i cen energii;

- utratę konkurencyjności energetyki konwencjonalnej;

- $\quad$ wymuszoną budowę drogiej energetyki jądrowej (skąd środki na inwestycję?);

- $\quad$ konieczność budowy bloków gazowych - wzrost uzależnienia energetycznego Polski;

- utratę konkurencyjności: polskiego przemysłu, budownictwa, transportu (w tym pasażerskiego) i rolnictwa;

- utratę krajowych benefitia loci.

Jak wiadomo, ,kula u nogi” polskiej energetyki jest specyficzna struktura bilansu energetycznego z przeważającym udziałem węgla kamiennego i węgla brunatnego na poziomie krajowego zużycia nośników pierwotnych, a jednocześnie skromnych możliwości pozyskania krajowego gazu ziemnego. Potrzeba dywersyfikacji bilansu energetycznego jest obciążona znacznymi wydatkami na import gazu ziemnego, na których znaczący wzrost Polska nie może sobie pozwolić, oraz niepewnością i ryzykiem związanymi z uwarunkowaniami geopolitycznymi. Te uwarunkowania zdecydowanie wyróżniają Polskę na tle państw członkowskich Unii Europejskiej. Specyficzna sytuacja stanowi poważne zamknięcie możliwości Polski dotyczących realizacji restrykcyjnej polityki klimatyczno-energetycznej Unii Europejskiej i naprawdę wielkie wyzwanie wobec konieczności wspierania rozwoju zrównoważonego w europejskim rozumieniu. To także wywołuje systematyczny i trudny do przełamania konflikt Polski z Unią Europejska. Polska, wstępując do Unii Europejskiej, zgodziła się na bardzo wysokie wymagania w stosunku do ochrony środowiska, natomiast nie podpisywała zobowiązań w sprawie ochrony klimatu.

Problemem Polski jest także to, że czas na pertraktacje o odrębne potraktowanie w Unii Europejskiej praktycznie się skończył, a osamotniona Polska niewiele już może osiągnąć na arenie Unii Europejskiej, aby złagodzić wymogi i zmniejszyć obciążenie polskiej gospodarki i społeczeństwa. W związku z tym, również perspektywy energetyki węglowej rysują się w ciemnych barwach. Arbitralny Market Stability Reserve (MSR) od 2019

\footnotetext{
12 Największe korzyści z unii energetycznej odniesie energetyka niemiecka i jej Energiewende, ponieważ techniczne ujednolicenie systemów elektroenergetycznych państw Unii Europejskiej stanie się dobrym amortyzatorem ryzyka i niepewności związanych z nieprzewidywalną pracą niestabilnych wiatrowych i solarnych źródeł energii elektrycznej. Dopóki energetyka odnawialna nie dopracuje się efektywnych metod magazynowania energii elektrycznej na skale przemysłowa, dopóty stabilność wewnętrznych systemów energetycznych może zapewnić alimentacja energetyki konwencjonalnej oraz rozpływy kołowe (wymuszony eksport).
} 
roku przyspieszy procesy „zwijania” polskiego górnictwa węgla kamiennego i energetyki węglowej. Procesy te dotkną nie tylko krajową elektroenergetykę, ale zarazem, a może przede wszystkim, sektor ciepłowniczy. Społeczne postrzeganie problemów ciepłownictwa w Polsce jest daleko słabsze niż górnictwa, elektroenergetyki, OZE i efektywności energetycznej - nieproporcjonalne do znaczenia w systemie energetycznym kraju i wagi barier rozwoju. Z reguły dyskusja publiczna pomija kwestie ciepłownictwa. Jednakże zaspokojenie potrzeb cieplnych budownictwa mieszkaniowego nie może być traktowane marginesowo nie tylko pod względem zapewnienia komfortu cieplnego w strefie klimatycznej Polski, ale również z tej racji, że opał i energia cieplna kształtuja 4/5 łącznych wydatków budżetów domowych na energię ${ }^{13}$. Ceny ciepła zatem maja znacznie większy ciężar gatunkowy niż nagłośniana drażliwość społeczna cen energii elektrycznej. Ponadto, ciepło, w przeciwieństwie do energii elektrycznej, nie jest dobrem importowalnym, a jedynie wytwarzanym i użytkowanym in situ.

Wielką niewiadomą jest rozdział darmowych uprawnień dla poszczególnych branż przemysłu i energetyki, w tym również dla ciepłownictwa, które w sposób ewidentny ucierpi na zmianach EU ETS i systematycznym ograniczaniu darmowych pozwoleń. Nota bene rozwój ciepłownictwa zasadniczo jest zgodny z zasadami i wymogami rozwoju zrównoważonego przez pozytywny wpływ na: ograniczenie emisji gazów i pyłów do atmosfery (także $\mathrm{CO}_{2}$ ), poprawę efektywności energetycznej oraz substytucję niskiej emisji. Presja ekologiczna zarówno gospodarki rozdzielonej, jak i gospodarki skojarzonej ciepłownictwa jest zdecydowanie mniejsza niż presja ogrzewnictwa indywidualnego i małych źródeł ciepła (niska emisja). W szczególności gospodarka skojarzona daje oszczędność około 1/4 paliwa na wytworzenie tej samej ilości energii finalnej, co przekłada się na rozmiary emisji zanieczyszczeń.

Jednym z kierunków restrukturyzacji źródeł energii jest zwiększenie zużycia gazu ziemnego. Jest to optymalne paliwo, które ma wiele zalet. Po pierwsze, przemiany gazu poprawiają efektywność energetyczną. Po drugie, jako paliwo benchmarkowe zapewnia umiarkowaną emisję $\mathrm{CO}_{2}$, a w konsekwencji pozwala na spełnienie emisyjnych wymogów Unii Europejskiej. Po wygaśnięciu mirażu eldorado gazu łupkowego z perspektywy „ugazowienia” polskiej energetyki jest ograniczone. Polska gospodarka jako taka bardzo słabo „ssie” gaz ziemny, gdyż od wielu lat roczna konsumpcja gazu ziemnego znajduje się na zbliżonym poziomie (13-14 $\left.\mathrm{mld}^{3}\right)$. Można się zastanawiać, czy gaz ziemny (jeśli występują ograniczenia ilościowe) nie powinien być przeznaczony w pierwszej kolejności na nowoczesne jednostki wytwórcze dla mniejszych ciepłowni komunalnych, które ze względu na wymogi dyrektywy IED muszą zostać zamknięte i zastapione nie tyle modernizowanymi kotłami węglowymi, co nowoczesnymi źródłami gazowymi. Tam bowiem inne technologie niskowęglowe nie mają szans na wdrożenie. Ciepłownictwo wielkoskalowe, źle postrzegane w Unii Europejskej, nolens volens długo jeszcze w Polsce będzie musiało korzystać z węgla z negatywnymi konsekwencjami tego stanu.

13 Polski system ciepłowniczy należy do największych w Europie zarówno pod względem mocy zainstalowanej źródeł ciepła, jak i liczby odbiorców ciepła zdalaczynnego. Ponad 40\% mieszkańców miast korzysta z ciepła zdalaczynnego, a w wielkich miastach wskaźnik ten dochodzi do $60 \%$. 
Za najważniejszy wpływ wewnętrzny związany z sektorem gospodarstw domowych należy uznać rozszerzanie się sfery ubóstwa energetycznego. De facto już obecnie połowa polskich gospodarstw domowych znajduje się w sferze ubóstwa energetycznego według kryteriów państw członkowskich Unii Europejskiej, znacznie bogatszych niż Polska, ponieważ średnie wydatki na opał, paliwo i energię od 10 lat przekraczają 10-procentowy udział w budżetach domowych. W świetle strategii i planów Unii Europejskiej nie ma nadziei na zahamowanie wzrostu cen energii, przez co pewne staje się zwiększenie obciążeń gospodarstw domowych z tego tytułu.

Utrzymanie konwencjonalnej elektroenergetyki i ciepłownictwa wiąże się z utrzymaniem miejsc pracy zarówno w energetyce, jak i w polskim górnictwie węglowym. Eliminowanie węgla ze struktury bilansu energetycznego wywołuje ważny problem społeczno-polityczny. W warunkach szybkiego spadku popytu na węgiel jest bardzo trudno przeprowadzić reformę sektora węglowego. Procesy restrukturyzacji górnictwa są w Polsce spóźnione. Utrata miejsc pracy w górnictwie węglowym nie zostanie skompensowana nowymi w energetyce nowoczesnej w równej mierze w stosunku do liczby, jak i miejsca. Szans na bezkonfliktowe rozwiązania w górnictwie węglowym praktycznie nie ma, co bezpośrednio grozi publicznymi demonstracjami.

\section{Podsumowanie}

Rozwój zrównoważony jest właściwą odpowiedzią na globalne problemy: ekologiczne, energetyczne, społeczne, polityczne i gospodarcze, jako racjonalna koncepcja miarkowania ,apetytu” gospodarki i społeczeństwa na zasoby naturalne oraz zintegrowanego podejścia do rozwoju ładu: ekologicznego, społecznego i gospodarczego. Do koncepcji rozwoju zrównoważonego wielki wkład wniosły heterodoksyjne dyscypliny ekonomiczne, w tym przede wszystkim ekonomia ekologiczna.

Droga do zielonej gospodarki jest jeszcze długa, a dojście do zielonego kapitalizmu jest skomplikowane, ponieważ już teraz wymaga wyrzeczeń i poniesienia kosztów przez obecne pokolenie, aby zapewnić dobrobyt przyszłym pokoleniom. Dobre intencje nie wystarczą, gdyż są nieodzowne: realny altruizm, poświęcenie i zniwelowanie różnicy między słowami a czynami, aby osiagnąć trwałość na wymaganym poziomie.

Współcześnie pojmowany rozwój zrównoważony, szczególnie w Unii Europejskiej, jest znacznie węziej rozumiany $i$ interpretowany niż jego pierwotne koncepcje, ponieważ obecnie szczególny nacisk kładzie na ochronę klimatu i gospodarkę niskoemisyjną, a właściwie na dekarbonizację gospodarki. To podejście zasadniczo zmienia spektrum zadań i powinności w zakresie wspierania rozwoju zrównoważonego. Trwałość klimatyczna, mająca na celu zachowanie przezorności klimatycznej, dużo kosztuje. Koszty są olbrzymie i realne, korzyści zaś - przypuszczalne i spekulacyjne.

Niewatpliwie, w polityce klimatyczno-energetycznej Unii Europejskiej racjonalnym kierunkiem rozwoju jest promocja OZE i efektywności energetycznej. Natomiast wielki nacisk na redukcję $\mathrm{CO}_{2}$ wydaje się mało racjonalny i przedwczesny tak ze względów technologicznych i bilansowych, jak i politycznych (brak uzgodnień międzynarodowych). Konsekwentne wprowadzanie w życie unijnej koncepcji rozwoju zrównoważonego 
w zakresie redukcji emisji $\mathrm{CO}_{2} \mathrm{w}$ odosobnieniu (bez USA i Chin i innych gospodarek wschodzących) jest strategia zgubną dla Unii Europejskiej i poszczególnych państw członkowskich, a przy tym szkodząca klimatowi przez migrację energochłonnego przemysłu.

Polityka klimatyczno-energetyczna Unii Europejskiej stoi w sprzeczności z możliwościami i interesami Polski, co powoduje, że Polska była, jest i będzie w systematycznym konflikcie z Unią Europejska jako całością i z najważniejszymi jej członkami. Polityka ta jest dla Polski w wielu wymiarach niekorzystna, ponieważ ogranicza rozwój polskiego przemysłu i osłabia jego konkurencyjność, jak również stanowi trwały czynnik wzrostu cen energii finalnej i obciążeń budżetów domowych.

Przeprowadzenie transformacji polskiej energetyki w perspektywie 2020 i dalszej jest skomplikowanym zadaniem, wymagajacym wysiłku: organizacyjnego, technologicznego i finansowego, tym bardziej że możliwości uzyskania przez Polskę specjalnego statusu praktycznie wyczerpały się. Będzie to coraz trudniejsze w świetle rosnącego zaangażowania Unii Europejskiej w coraz bardziej ambitniejszą politykę klimatyczna. Ekonomicznie nieopłacalna walka z emisją $\mathrm{CO}_{2}$ w szczególny sposób odbije się na polskiej elektroenergetyce i ciepłownictwie.

W polskich uwarunkowaniach są potrzebne: rozwój, innowacje i modernizacja źródeł gospodarki energetycznej nie tylko na małą skalę, lecz także są nieodzowne źródła wielkoskalowe. Wielka skala gwarantuje znacznie wyższe efekty ekologiczno-oszczędnościowe niż źródła drobne. Przy czym ze względów bilansowych w Polsce niemożliwe i nierealne jest daleko idące zastapienie węgla gazem ziemnym i energia z OZE.

W rozmowach z Unią Europejską polski rząd ma słuszne prawo domagać się uwzględnienia naszej specyfiki bilansowo-geopolitycznej oraz poszukiwać dróg pomocy publicznej zapewniających inwestorom dostateczne warunki do podejmowania inwestycji nie wyłącznie w energetyce rozproszonej i małoskalowej, ale również w energetyce tradycyjnej i wielkoskalowej.

\section{Literatura}

Ayres R., 1998, Eco-thermodynamics, "Ecological Economics", 26.

Collados C., Duane T., 1999, Natural Capital and Quality of Life, "Ecological Economics", 30.

Costanza R., 2001, Visions, Values, V aluation, and the Need for an Ecological Economics, "Bioscience", 51, no. 6.

Daly H., 2002, Sustainable Development, "Invited address, World Bank", April 30, Washington, DC.

Farber S., Costanza R., Wilson M., 2002, Economic and Ecological Concepts for Valuing Ecosystem Services, "Ecological Economics", 41.

Górka K., 2010, Kwestie terminologične w ewolucij polityki ekologičnej, [w:] Rozwój polityki ekologicznej w Polsce i UE, J. Famielec (red.), Wydawnictwo Uniwersytetu Ekonomicznego w Krakowie, Kraków. 
Hediger W., 1999, Reconciling "Weak" and "Strong" Sustainability, "International Journal of Social Economics", 26, no. 7-9.

Jeżowski P., 2007, Kategoria rozpoju zrónnoważonego w naukach ekonomicznych, [w:] Ekonomiczne problemy ochrony środowiska i rozwoju zrównoważonego w XXI wieku, P. Jeżowski (red.), Oficyna Wydawnicza Szkoły Głównej Handlowej, Warszawa.

Jeżowski P., 2012, Rozwój zrównoważony a zielony kapitalizm, [w:] Kapitalizm cazy kapitalizmy. Anatomia ewolucji formacji, J. Osiński (red.), Oficyna Wydawnicza Szkoły Głównej Handlowej, Warszawa.

Lambrecht M., Thierstein A., 1998, Nachbaltige Entwicklung und Raumordnung, „Raumforschung und Raumordnung", no. 2-3.

Marechal K., 2009, An Evolutionary Perspective on the Economics of Energy Consumption, "Journal of Economic Issues", 43, no. 1.

Mulder P., van der Bergh J., 2001, Evolutionary Economics Theories of Sustainable Development, "Growth and Change", 32, no. 1.

Pearce D., Atkinson G., 1998, The Concept of Sustainable Development, "Swiss Journal of Economics and Statistics", 134, no. 3.

Rennings K., Wiggering H., 1997, Steps toward Indicators of Sustainable Development, "Ecological Economics", 28, no. 1.

Rogall H., 2010, Ekonomia zrównoważonego rozpoju, Wydawnictwo Zysk, Poznań.

Unia Energetycżna postusy do promocji polityki klimatycznej, „Biznes Alert”, 15.05.2015.

Wackernagel H., Rees W., 1997, Perceptual and Structural Barriers to Investing in Natural Capital, "Ecological Economics", 20, no. 1.

Żylicz T., 2004, Ekonomia środowiska $i$ zasobón naturalnych, Polskie Wydawnictwo Ekonomiczne, Warszawa. 